\author{
MACIEJ SEROWANIEC \\ Chair of Constitutional Law \\ Faculty of Law and Administration \\ Nicolaus Copernicus University in Toruń \\ mserowaniec@umk.pl \\ ORCID ID: 0000-0003-4693-7977
}

\title{
EUROPEAN SEMESTER-SPRING PACKAGE: RECOMMENDATIONS FOR POLAND ON THE SOCIO-ECONOMIC RESPONSE TO THE COVID-19 PANDEMIC ${ }^{1}$
}

\begin{abstract}
SUMMARY
Extraordinary circumstances, and the COVID-19 outbreak undoubtedly meets this criterion, therefore require extraordinary solutions, including in the EU and national decision-making process to prevent their escalation. Out of concern for the stability of the economic systems of European Union Member States, it has become necessary to introduce procedures to effectively counteract the effects of COVID-19, including in the area of economic activity. An important role in monitoring these initiatives is now played by the European Semester procedure, which allows Member States to discuss their policies, exchange best practices and agree on joint actions for the future to counteract the effects of COVID-19. This paper aims to present the recommendations for Poland, which were formulated in the framework of the 2020 Spring European Semester.
\end{abstract}

KeYwORDS: COVID-19, European Semester, recommendations, state budget, economic situation.

1 The paper is written on the BETKOSOL framework. The project BETKOSOL (Greant Agreement (GA) NO. 101015421) was funded by the European Union's HERCULE III programme 


\section{INTRODUCTION}

The Member States of the European Union are currently struggling with the consequences of the COVID-19 epidemic, which has developed into a serious socio-economic crisis before our eyes. It is hitting social relations, economic stability and the possibility of realising fundamental human rights. Health care measures and restrictions on movement, affecting production, demand, and trade, have reduced economic activity and led to a rise in unemployment, a sharp fall in corporate profits, increased public deficits, and widening inequalities within and between the Member States. Therefore, it has become a priority for the European Union to take various measures and initiatives aimed at minimising the negative economic and social effects of the crisis, any fragmentation of the single market, and major divergences and imbalances in the EU economy. The Spring 2020 European Semester package played an extremely important role in coordinating the economic response to the effects of the COVID-19 pandemic at the European level. It formulated some important recommendations for individual European Union Member States to combat and counteract the socio-economic effects of the pandemic. This study aims to present and characterise the recommendations addressed to Polish state authorities ${ }^{2}$.

\section{ESSENCE AND OBJECTIVES OF THE EUROPEAN SEMESTER}

The so-called European Semester procedure was established by the decision of the European Council (in the form of conclusions) of 17 June $2010^{3}$ based on the Commission's communication of 12 May $2010^{4}$ and formally confirmed

2 For more on the impact of pandemic COVID-19 on Polish legal regulations, see M. Loehnig, M. Serowaniec, Z. Witkowski (eds.), Pandemic Poland. Impacts COVID-19 on Polish Law, Brill Publishing House 2021.

3 See point 11 of the Conclusions of the European Council of 17 June 2010, Brussels, available online: https://www.consilium.europa.eu/uedocs/cms_data/docs/pressdata/PL/ec/115354. pdf.

4 Communication from the Commission to the European Parliament, the Council, the European Central Bank, the European Economic and Social Committee and the Committee of the Regions: Reinforcing economic policy coordination, COM(2010) 250 final. 
by the so-called 'six-pack' ${ }^{5}$ regulating new rules of economic governance in the EU), as a mechanism for closer coordination of economic and budgetary policies of EU Member States ${ }^{6}$. The introduction of the European Semester was thus to contribute to broader inclusion of the European dimension in the planning of national economic strategies and the provision of funds for the implementation of the 'Europe 2020' objectives in the budgets of Member States ${ }^{7}$. This process comprises three parallel and interrelated tracks: macroeconomic surveillance, thematic coordination and fiscal surveillance. The first two tracks concern issues covered by the National Reform Programmes. The third one concerns issues covered by the Stability or Convergence Programmes prepared under the Stability and Growth Pact. In addition, the European Semester introduces synchronisation of updating the National Reform Programmes and the Stability or Convergence Programmes. The first edition of the Semester took place in 2011.

The annual cycle of the European Semester includes several elements. At the end of the year (usually in November), the European Commission publishes a communication: Annual Growth Survey. It defines priority courses of action for the Union for the following year. In March, based on the Annual Growth Survey, the European Council identifies the Union's challenges and formulates the economic policy guidelines. In April, Member States then submit to the Commission updated National Reform Programmes and Stability or Convergence Programmes, taking account of guidance from the European Council ${ }^{8}$. Between May and June, the Commission assessed these documents, which, based on its assessment, issues recommendations to the Member States (so-called country-specific recommendations). They are finally adopted by the Council and the European Council in July. Recommendations are the most important element of the Semester and formally end the process. Although

5 It consists of the Council Directive 2011/85/EU, 4 Regulations of the European Parliament and of the Council $(1173 / 2011,1174 / 11,1175 / 11,1176 / 11)$ and the Council Regulation (1177/11), Official Journal of the EU L 306 of 23 November 2011.

6 T. Woźnicki, Semestr europejski w Sejmie RP. Aspekty instytucjonalne i prawne, „Przegląd Europejski” Nr 1 (35), 2015, pp. 145-146.

7 The Europe 2020 strategy has set targets for each Member State in various areas (employment, research and development, greenhouse gas emissions, renewable energy, energy efficiency, early school leaving, higher education, reducing the population at risk of poverty or social exclusion) as well as measures for achieving them.

8 T. Woźnicki, op. cit., s. 146. 
they have no binding force, they undoubtedly have political significance, all the more so if a given country is subject to the excessive deficit procedure. Therefore, Member States should consider when working on their national budgets under the so-called national Semester. At the same time, the euro area countries submit their draft budgetary plans to the Commission and the Eurogroup by mid-October to adopt their budgets by the end of the year'. As an aside from these considerations, it is worth noting that the European Semester mechanism also involves the national parliaments of the EU Member States, which are responsible for adopting budgets and scrutinising governments ${ }^{10}$. Their involvement in the European Semester is intended to give the process greater democratic ${ }^{11}$ legitimacy.

\section{RECOMMENDATION OF THE COUNCIL OF THE European Union on Poland's National ReForm PROGRAMME FOR 2020 AND 2021}

At the outset, it is worth noting that since 2018 Poland has been included in the preventive part of the Stability and Growth Pact. On 13 July 2018. Indeed, the Council recommended Poland ensure that the nominal growth rate of net public primary expenditure does not exceed $4.2 \%$ in 2019 , corresponding to an annual structural adjustment of $0.6 \%$ of GDP. The European Commission's overall assessment also confirmed a significant deviation from the recommended adjustment path towards the MTO in both 2019 and 2018 and 2019 combined. In the submitted convergence programme

9 Z. Szpringer, Sytuacja budżetowa państw UE w ramach funkcjonowania Semestru Europejskiegozalecenia dla Polski, “Analizy BAS” Nr 15 (82), 2012, pp. 3-4.

10 C. Fasone, How are Parliaments involved in the European Semester?, Revue de l'euro, no. 51, 2017, https://resume.uni.lu/story/how-are-parliaments-involved-in-the-european-semester, p. 1-5.

11 Cf. in more detail M. Halleberg, B. Marzinotto, G.B. Woff, How effective and legitimate is the European Semester? Increasing role of the European Parliament, "Brugel Working Paper" No. 09, 2011, http://aei.pitt.edu/32516/1/How_effective_and_legitimate_is_the_European_ semester_Increasing_role_of_the_European_parliament_(English)-1.pdf [accessed 13 December 2020]; M. Serowaniec, The integrative responsibility of national parliaments in the era of the economic crisis in the Eurozone, "Studies in the field of legal and organisational sciences. Miscellanea” vol. V, 2015, pp. 163-177. 
for 2020, the government planned the deterioration of the headline balance from a deficit of $0.7 \%$ of GDP in 2019 towards a deficit of $8.4 \%$ of GDP in 2020. According to the government, the general government debt-to-GDP ratio, after falling to 46.0 per cent of GDP in 2019 , is expected to rise to 55.2 per cent in 2020 .

The macroeconomic and budgetary outlook is affected by the high uncertainty caused by the COVID-19 pandemic. Indeed, in response to the pandemic and as part of a coordinated EU approach, Poland has mobilised budgetary resources to strengthen the capacity of its health system, contain the pandemic and help those people and sectors that are particularly affected. The 2020 convergence programme indicates that the total value of these budgetary measures is $3.2 \%$ of GDP. They include, among other things, benefits for the self-employed and those employed under non-standard employment contracts, exemptions of enterprises from social security contributions (these contributions will be paid from the state budget) and wage subsidies for certain enterprises. In addition, Poland has announced measures that will contribute to supporting the liquidity of companies, such as loan guarantees for companies, while not having a direct budgetary impact. According to the authorities' announcements, the European Commission's forecast is based on the assumption that loans equivalent to around $23 / 4$ percentage points of GDP will be transformed into grants and thus recognised as an expenditure in 2020. Overall, the action taken by Poland is in line with the guidance set out in the Commission's Communication on a coordinated economic response to the COVID-19 outbreak. Fully implementing these measures and subsequently reorienting fiscal policy towards a prudent medium-term budgetary position, when economic conditions allow, will contribute to maintaining the sustainability of public finances in the medium term.

Due to the outbreak of the COVID-19 pandemic, Poland finds itself in a new social and economic situation. For the first time in almost thirty years, a recession is a forecast for 2020 . So far, the most negative effects have been observed in the services sector (including transport, retail and wholesale trade and recreation) and the manufacturing sector due to disruptions in supply chains. To offset the imposed restrictions, the government has mobilised a number of measures amounting to around 9\% of Poland's GDP (deficit-increasing measures and liquidity support measures together), including 
EU funding. Support also comes from the National Bank of Poland, which provides liquidity measures. Government support focuses on stabilising the economy in the short term by supporting workers' incomes, providing financing to companies that have seen their incomes fall, strengthening the health sector's resilience and responsiveness, and strengthening the financial system. It also includes an investment programme to support recovery in the medium term. However, there remains strong public demand for policy action, including introducing exemptions from social security contributions, benefits for workers in enterprises that suspend operations and providing micro-enterprises with access to loans. In Poland, COVID-19 is projected to contribute to a $4.3 \%$ fall in GDP in 2020 , followed by a $4.1 \%$ recovery in $2021^{12}$.

The COVID-19 pandemic necessitated unprecedented measures in the health system. Substantial expenditure was incurred on purchasing health-related equipment and protective measures, increasing hospital and laboratory capacity, and strengthening staffing. Before the outbreak of the COVID-19 pandemic, public expenditure on the health system represented 4.8 per cent of GDP, below the EU average of 7 per cent of GDP in 2018. This low level of public spending, combined with the suboptimal allocation of funds, hinders access to the health system. In 2018, the percentage of the Polish population reporting unmet needs for medical examinations was 4.2 $\%$, significantly higher than the percentage at the Union level (2\%). The number of practising doctors and nurses relative to the population remains one of the lowest in the Union, and the distribution of health professionals in the country is uneven. Public health, e-health and primary health care, which are essential for improving prevention and access to the system and increasing its resilience to future challenges, remain underdeveloped. The pandemic has impacted long-term care facilities, which house many people in the high-risk group ${ }^{13}$.

The outbreak of the COVID-19 pandemic has severely affected the working conditions of enterprises, especially small and medium-sized enterprises (hereinafter SMEs) and micro-enterprises. Offering remote working

12 Ibidem, p. 5.
Ibid. 
solutions is a challenge-only in one in ten Polish companies is the level of digital transformation advanced enough to enable rapid adaptation to new conditions. In the case of SMEs, one of the main obstacles to this kind of transformation is the low level of digital skills among owners, managers and employees. The use of digital technologies in public administration is key to ensure the delivery of public administration services and to steer the necessary resources to monitor and manage the crisis. In addition, efficient digital public services reduce unnecessary regulatory and administrative burdens, which can be crucial in the recovery phase.

To mitigate the effects of the COVID-19 pandemic, the Polish government is offering liquidity assistance to affected enterprises, particularly SMEs and micro-enterprises, in the form of guarantees, loans and conditional grants. Furthermore, the National Bank of Poland supports the government measures, inter alia, through a programme of purchases of government bonds on the secondary market and significant reductions in interest rates. Effective and rapid implementation of these measures and effective outreach through intermediaries are essential to facilitate the continuation of the business sector and support the economic recovery. However, the design and implementation of these measures should consider the resilience of the banking sector and monitor the stability of the financial system. In addition, allowing deferred payment of taxes and social security contributions and accelerating contractual payments by public authorities will also improve the cash flow of businesses affected by the crisis.

A stable and predictable business environment and a favourable investment climate play an important role in post-pandemic recovery. The independence, efficiency and quality of the justice system are essential in this respect. Legal certainty, including access to independent courts and confidence in the quality and predictability of regulatory policies and institutions, are also key factors for the functioning of the Single Market and for maintaining Poland's position in European supply chains after a pandemic. In addition to long-standing concerns about the rule of law in Poland-which the Commission has previously highlighted and some of which have already been addressed by the Court of Justice of the European Union in its 
rulings-further concerns have emerged in the light of recent events which threaten the functioning of the Polish and EU legal order ${ }^{14}$.

As the recommendations also aptly point out, a sound and stable regulatory environment should also underpin future growth and private investment. Lack of consultation with the social partners hurts the stability and certainty of the business environment and the quality of legislation. The obligation to consult the public has been introduced for draft laws proposed by the Council of Ministers. At the same time, for proposals falling under the alternative legislative path, such as parliamentary proposals, consultations are either not carried out or not mandatory. This inconsistency also adversely affects the quality of legislation adopted. In addition, the quality of social dialogue has deteriorated in recent years, mainly because consultation is absent from policy-making or consultation periods are very short. Ensuring sufficient time for consultation, making better use of stakeholders' views on draft laws and policy documents and minimising the exclusion of laws from consultation would increase the involvement of social partners and contribute to improving the quality of law-making. The Social Dialogue Council is part of the institutional framework for tripartite social dialogue. However, the legal provisions adopted in April 2020 weaken the autonomy of social partners in the Council for Social Dialogue, with the risk of further reducing the effectiveness of social dialogue in Poland.

The COVID-19 pandemic has also affected the labour market and caused a reversal of the downward trend in unemployment levels recorded in recent years. The unemployment rate, which reached $3.3 \%$ in 2019 , is projected to rise to around $7.5 \%$ in 2020 , followed by a slight improvement to $5.3 \%$ in 2021. However, there is a serious risk that these short-term effects become more structural in the medium term, especially for vulnerable groups. A temporary mechanism of reduced working hours could be an effective way to preserve jobs with appropriate measures to encourage companies to use it. At the same time, despite positive developments before the COVID-19 crisis, labour market participation of some groups, notably women, low-skilled people, older people and people with disabilities and their carers, remains low. Migration from non-EU countries is helping to alleviate labour shortages, but maintaining a steady flow of migrant workers can be difficult due

14 Ibidem, p. 8. 
to border control restrictions. According to European Union authorities, the wider introduction of flexible forms of work organisation, including remote working schemes and flexible working hours, in particular within permanent forms of employment, can therefore help to respond to the crisis, as well as provide support for people from groups with lower activity rates to find permanent employment ${ }^{15}$.

As the recommendations aptly point out, mitigating the social impact of the COVID-19 pandemic, maintaining social cohesion and promoting economic recovery also requires the provision of substantial protective measures. In recent years, Poland has introduced an extensive social transfer programme, including a universal child benefit and an additional one-off benefit to be paid annually to pensioners, worth almost 2.5 per cent of GDP. These measures are not subject to income criteria, and there is scope for better targeting. At the same time, the scope for social benefits is small for those on the lowest incomes. The largest increase in extreme poverty recorded in the 2019 Household Budget Survey was observed for individuals or families living on social benefits (other than pensions and disability benefits), indicating weaknesses in the social security system.

Moreover, not all employment contracts provide access to social protection, inadequate unemployment benefits, maternity benefits, sickness benefits and invalidity pensions. This makes some of the workers affected by the emergency measures even more vulnerable and at risk of falling into poverty. In addition, the level of benefits ensuring a minimum income is below the EU average.

The recommendations addressed to Poland also noted that the sudden suspension of classes at all levels of education posed a systemic challenge. To not exacerbate inequalities, it is crucial to ensure that all learners-especially those from disadvantaged backgrounds-have access to distance learning. However, in 2018, the households of almost 330,000 learners did not have a computer with internet access. As a result, a significant proportion of teachers lack the skills needed to teach digitally. At the same time, many parents find it difficult to support digital learning and home education. Indeed, the COVID-19 crisis has highlighted the overall structural challenges to raising

15 Ibidem, p. 6. 
digital skills. Nearly half of adults lack basic digital skills, and the overall number of adult learners is well below the EU average. Moreover, recent vocational education reforms have not encouraged enough employers to participate, so the potential of on-the-job training remains partly untapped. The teacher shortage, which is beginning to be felt, points to the need to increase the attractiveness of the teaching profession ${ }^{16}$.

\section{SUMMARY}

Even in the face of the COVID-19 pandemic, it is important to remember that greater public-sector involvement in the economy should be an exceptional and temporary phenomenon. It must not be used to permanently expand the state's presence in the economy and allow politically appointed officials to take control of private-sector assets. This is accompanied by the threat of increasing centralisation of the state and attempts to undo the achievements of local government institutions in the management of public funds. In turn, the huge expansion of public spending may threaten the future with increased fiscalism and new social conflicts in connection with the need to balance state finances after the "era" of the pandemic ${ }^{17}$. For this reason, the recommendations of the Council of the European Union on the national reform programmes, prepared within the framework of the European Semester for the individual Member States of the European Union, can be an important instrument for stabilising the national system of public finance.

6 Ibid.

Ibid. 


\section{REFERENCES}

Fasone, C. (2017). How are Parliaments involved in the European Semester? Revue de l'euro, no. 51.

Halleberg, M., Marzinotto, B., Woff, G. B. (2011). How effective and legitimate is the European Semester? Increasing role of the European Parliament. Brugel Working Paper, No. 09.

Loehnig, M., Serowaniec, M., Witkowski, Z. (eds.) (2021). Pandemic Poland. Impacts COVID-19 on Polish Law. Brill Publishing House.

Serowaniec M. (2015). The integration responsibility of national parliaments in the era of the economic crisis in the Eurozone. Studia z zakresu nauk prawnoustrojowych. Miscellanea, vol. V.

Szpringer, Z. (2012). Sytuacja budżetowa państw UE $w$ ramach funkcjonowania Semestru Europejskiego-zalecenia dla Polski (Budget situation of the EU states in the framework of the European Semester functioning-recommendations for Poland). Analizy BAS” Nr 15 (82). 2012.

Woźnicki, T. (2015). Semestr europejski w Sejmie RP. Aspekty instytucjonalne i prawne. Przegląd Europejski, Nr 1 (35). 